Original Research Paper

\title{
Radiological Risks Assessment of Ogun State Drinking Water
}

\author{
Justina Ada Achuka, Usikalu Mojisola Rachael and Oyeyemi Kehinde David
}

Physics, Covenant University, Nigeria

Article history

Received: 24-10-2016

Revised: 25-04-2017

Accepted: 03-05-2017

Corresponding Author: Miss Justina Ada Achuka Department of Physics, Covenant University, Nigeria Email:

justina.achuka@covenantuniversity.edu.ng

\section{Introduction}

Life will not survive on earth without water. It is the most important resource to man after air. Various sources of water exist, but the most accessible is that which is readily available to individual community. Groundwater harnessed as dug or drilled well, is the major source of water for homes and industries in the study area. Several researches have attested to the degree of groundwater usage in the study area (Alausa et al., 2014; Adekunle et al., 2013; Aladejana and Talabi, 2013; Odukoya et al., 2010; Orebiyi et al., 2008). Even in Nigeria, the inadequacy of public water has made well water the resulted alternative in meeting the required need for water. The study of Akujieze et al. (2003) revealed the abundant potential of groundwater resource in Nigeria. Yet, more than half of the population of Nigerian does not have access to safe drinking water (Orebiyi et al., 2010). The same challenge has been noted in the developing countries (Jacobsen et al., 2012; AMCOW, 2012; UNEP, 2010). Ground water is known to be the second smallest of the four main pools of water on earth, yet ground water besides surface water are the components of the hydrologic system that humans use most (Winter et al., 1998). It is therefore necessary to ensure that this indispensable resource is proven healthy for human use.

WHO (2011), reported that several radioactive compounds are being released into the environment. These compounds find their way into drinking-water supplies through human activities and human-made sources. Kelleher (2015) reported that industry and agriculture are putting usable groundwater at risk. Literature also confirms varying concentrations of radionuclides in our water body (Rachkova and Shuktomova, 2015; Nwankwo and Balogun, 2013; Ndontchueng et al., 2013; Peterson et al., 2007; Kurttio et al., 2006). Drinking water is one of the pathways to human exposure to radiation. Evidence exist from both human and animal studies that radiation exposure at low to moderate doses may increase the long-term incidence of cancer (WHO, 2011). They noted that, no deleterious radiological health effects are expected from 
consumption of drinking-water if the concentrations of radionuclides are below the guidance levels (WHO, 2011).

A case-cohort study of drilled wells in Finland witnessed a small evidence of increased risk of bladder or kidney cancers from the ingestion of radionuclides through drinking from these wells (Kurttio et al., 2006). A population based case control study was reported in Thailand. The results showed a strong dose-dependent association between consumption of radium contaminated shallow well water and cancer of the upper digestive tract. Cancer risk also increased with the consumption of fresh water fish in the study area (Phatcha et al., 2006). Similar case control study identified significant correlation between other type of cancer and ingested radionuclides (Auvinen et al., 2002; 2005). Contrariwise, ecological studies in Harris country associated birth defects to ingestion of high radium in water (Cech et al., 2008). Diverse epidemiological studies that estimated cancer risk against ingestion of radionuclides in water has been reported (Canu et al., 2011). Radionuclides embedded in the earth crust are the major contributor to increased radiation in ground water resources (Phatcha et al., 2006; UNSCEAR, 2000).

Ogun State is known for quarrying with rocks blasting and the quest for limestone. These activities among others have left the environment with high radionuclides content. Also, the study area is characterized with varying degrees of geologic formations (Adekunle et al., 2013). Rocks formation known for poor groundwater bearing properties and high concentrations of radionuclides are embedded in this vicinity (Farai and Vincent, 2006). Even, high level of radionuclides concentrations have been anticipated in part of the study area (Jibiri et al., 2010). Groundwater occurrence in the area is limited to the fractured and in-situ weathered portions of the rocks. Movement of water is strongly influenced by topography and springs. Recharge is mainly by percolating rainwater and by seepage from adjacent surface water (Aladejana and Talabi, 2013). According to Winter et al. (1998), surface and ground water are hydraulically connected and commonly interact throughout all landscapes (Winter et al., 1998). They further affirm that groundwater flow paths vary greatly in length, depth and travel time from points of recharge to points of discharge in the groundwater system. When radionuclides are released to the environment, they persist until they are lost through radioactive decay, causing radiation exposures into the future (UNSCEAR, 2000).

Research has shown that access to safe drinking water is a prerequisite to poverty reduction (Orebiyi et al., 2010). Numerous diseases will be averted when ingested water is safe. Naturally occurring radionuclides in drinking-water are often less amenable to control (WHO, 2011). Therefore, it is important to assess the concentration of radionuclides in our drinking water, so that remedial actions can be taken in order to minimize radiation risks.

Hence, this study was embarked upon to assess the magnitude of radiological risks due to radionuclides contamination in drinking water of the study area. So that remediation that will enhance the safety of the populace will be implemented.

\section{Materials and Methods}

\section{Study Area}

Three industrial cities of Ogun State namely Abeokuta, Ijebu Ode and Idiroko were used for this study. The population of the study area is about 1.1 million with a growth rate of about $3.9 \%$ annually (NBS, 2012; Jacobsen et al., 2012). The geological map of Ogun State showing the study area is as shown in Fig. 1. Abeokuta is basically basement complex in origin, Ijebu Ode belong to the Abeokuta formation while Idiroko is majorly coastal plain sands. The basement complex rocks are of Precambrian age to early Palaeozoic age, consisting of quartzites and biotite schist, hornblende-biotite, granite and gneisses. They are characterized by various folds, structures of various degree of complexity, faults, foliation among others (Adekunle et al., 2013; Okeyode, 2012). The Abeokuta formation consists of grey sand intercalated with brown to dark grey clay (Okeyode, 2012). The coastal sand area of the study environment is in contact with recent alluvium. Groundwater of the study area is subjected to severe degradation due to quarry activities, sand mining and the likes (Adedeji et al., 2014; Aladejana and Talabi, 2013; Jibiri et al., 2010).

\section{Radiation Measurement}

A total of 20 well (drilled and dug) water samples were collected randomly at different locations and depths. The locations of the wells are widely spread out to ensure that every region of the study area was covered. This is to ensure a wide coverage for the measurement of the level of radionuclides contaminations of well water in the study area, since the locations are characterized by different geology and topography. Sample preparation was carried out as documented by the International Atomic Energy Agency (IAEA, 1989).

Chemical analysis of all the samples was conducted using standard techniques according to APHA (1999). Gamma spectrometry measurements were carried out with coaxial-type HPGe detectors (Canberra Industries Inc.) of $50 \%$ relative efficiency and having a resolution of 2.4 $\mathrm{keV}$ at $1.33 \mathrm{MeV}$ peak of ${ }^{60} \mathrm{Co}$. The system was set up to cover about $2 \mathrm{MeV}$ photon energy ranges over $4 \mathrm{k}$ channels. The detectors were properly shielded in lead castles. 


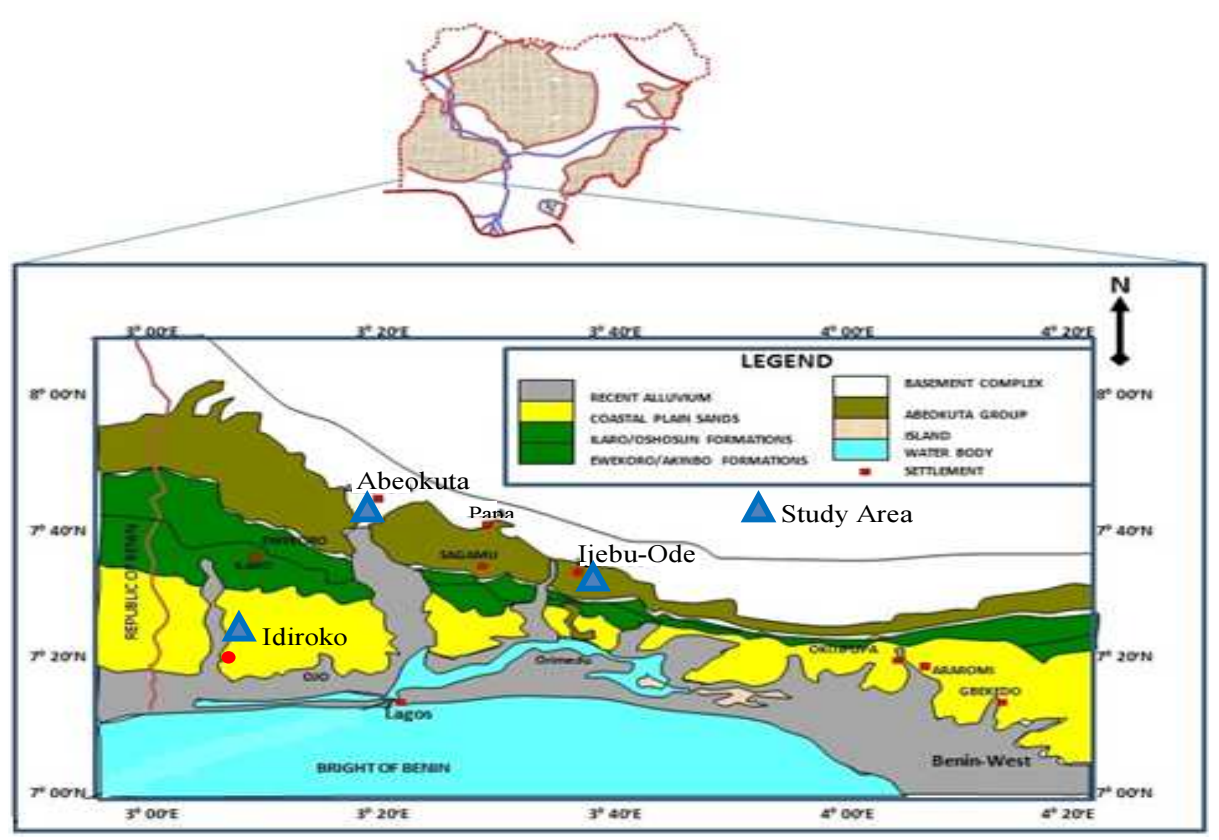

Fig. 1. Geological map of Ogun State showing the study area

Calibrations of the measuring system were carried out using certified reference standards for various radionuclides. Spectra analyses were performed with the Genie 2k spectrometry software, version 2.1 (Canberra Industries Inc). A library of radionuclides, which contained the energy of the characteristic gamma peaks for each nuclide analyzed and their corresponding emission probabilities, was built from the data supplied in the software. Each sample was counted for $86400 \mathrm{~s}$ to achieve minimum counting error. Specific activity of each radionuclide in water were expressed in $\mathrm{Bql}^{-1}$ of the water sample and corrected for the time elapsed time since the samples were collected from the well.

\section{Results}

The result of chemical parameters for 20 well water samples from three industrial cities of Ogun State namely Abeokuta, Ijebu Ode and Idiroko is presented in Fig. 2. All the values recorded fall within the World Health Organization (WHO) permissible level for drinking water quality.

The activity concentrations of ${ }^{40} \mathrm{~K},{ }^{210} \mathrm{~Pb},{ }^{224} \mathrm{Ra},{ }^{232} \mathrm{Th}$ and ${ }^{238} \mathrm{U}$ measured in the water are presented in Table 1. The concentration of ${ }^{40} \mathrm{~K}$ in all the water samples ranged from $0.10 \pm 1.08$ to $4.69 \pm 0.17 \mathrm{Bql}^{-1}$ with a mean of $1.86 \pm 1.70 \mathrm{Bql}^{-1}$. The activities for ${ }^{210} \mathrm{~Pb},{ }^{224} \mathrm{Ra},{ }^{232} \mathrm{Th}$ and ${ }^{238} \mathrm{U}$ are: Below Detection Limit (BDL) to $13.23 \pm 2.84$ $\mathrm{Bql}^{-1}$; BDL to $7.94 \pm 6.43 \mathrm{Bql}^{-1}$; BDL to $23.52 \pm 8.67 \mathrm{Bql}^{-1}$ and $\mathrm{BDL}$ to $12.37 \pm 2.50 \mathrm{Bql}^{-1}$ respectively and mean activities are: $7.93 \pm 2.40 \mathrm{Bql}^{-1} ; 3.60 \pm 1.25 \mathrm{Bql}^{-1}$; $8.48 \pm 2.10 \mathrm{Bql}^{-1}$; and $2.28 \pm 0.57 \mathrm{Bql}^{-1}$ respectively. The result presented in Fig. 3 showed that the activity concentration of ${ }^{238} \mathrm{U}$ was below the guidance level in all the water sampled but for Abk 7. However, the activity concentrations of ${ }^{210} \mathrm{~Pb},{ }^{224} \mathrm{Ra}$ and ${ }^{232} \mathrm{Th}$ are above the guidance level in all samples except Abk 4. The Guidance Level (GL) was adopted from the (WHO, 2011) water quality guidelines. Guidance level was not established for ${ }^{40} \mathrm{~K}$. It is known to be evenly distributed in the body; metabolic balance maintains its concentration in the body irrespective of the amount ingested (UNSCEAR, 2000).

The result depicted in Fig. 4 showed that ages 12-17 $\mathrm{y}$ are prone to higher risks from the ingestion of water from these wells than all the other age groups. Next to it is the infants (1-2 y), closely followed by the new born $(0-1 \mathrm{y})$ and the adults $(>17 \mathrm{y})$ are the least prone.

\section{Calculation of Total Annual Effective Dose}

The annual effective dose $(E)$ to an individual due to intake of natural radionuclides of ${ }^{210} \mathrm{~Pb},{ }^{224} \mathrm{Ra},{ }^{232} \mathrm{Th}$ and ${ }^{238} \mathrm{U}$ from drinking well waters of Ogun State is estimated using Equation 1:

$$
E=A_{C} I_{A} C_{F}
$$

where, $E$ is the annual effective dose to an individual due to the ingestion of radionuclides $\left(\mathrm{Sv} \mathrm{y}^{-1}\right) ; A_{c}$ is the activity concentration of radionuclides in the ingested drinking water $\left(\mathrm{Bql}^{-1}\right) ; I_{A}$ is the annual intake of drinking water $\left(1 \mathrm{y}^{-1}\right)$; and $C_{F}$ is the ingested dose conversion factor for radionuclides $\left(\mathrm{Sv} \mathrm{Bq}{ }^{-1}\right)$. For this study, $I_{A}(1$ $\left.\mathrm{y}^{-1}\right)$ values for the different age groups are: 200;260; $300 ; 350 ; 600$; and 730 for ages $0-1 \mathrm{y} ; 1-2 \mathrm{y} ; 2-7 \mathrm{y} ; 7-12$ $\mathrm{y} ; 12-17 \mathrm{y}$; and $>17 \mathrm{y}$ respectively (IAEA, 1996). $C_{F}$ values are adopted from ICRP (2012). 


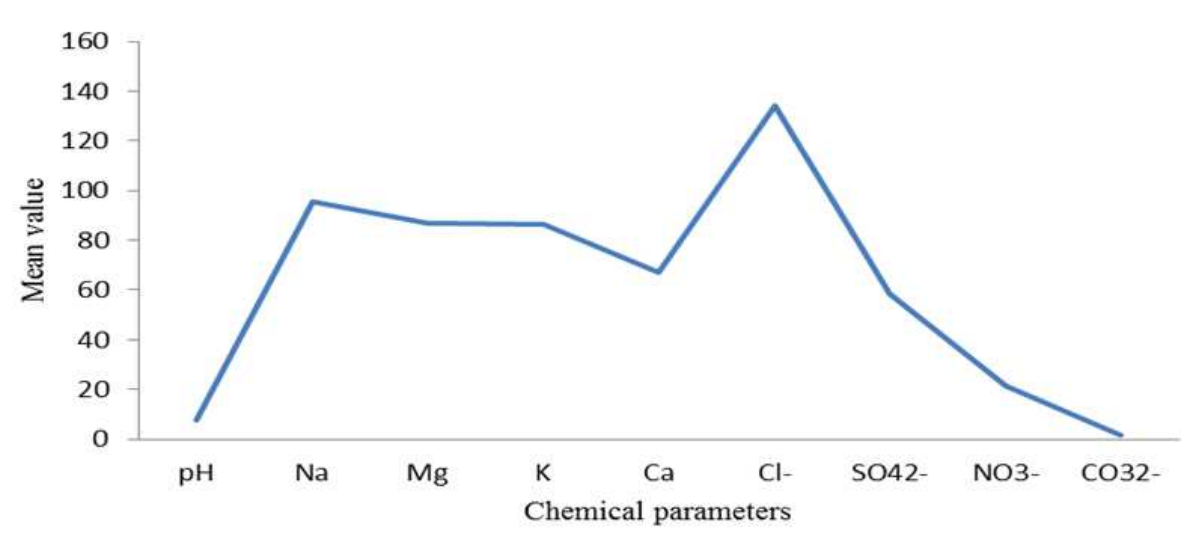

Fig. 2. Average chemical parameters in well water samples

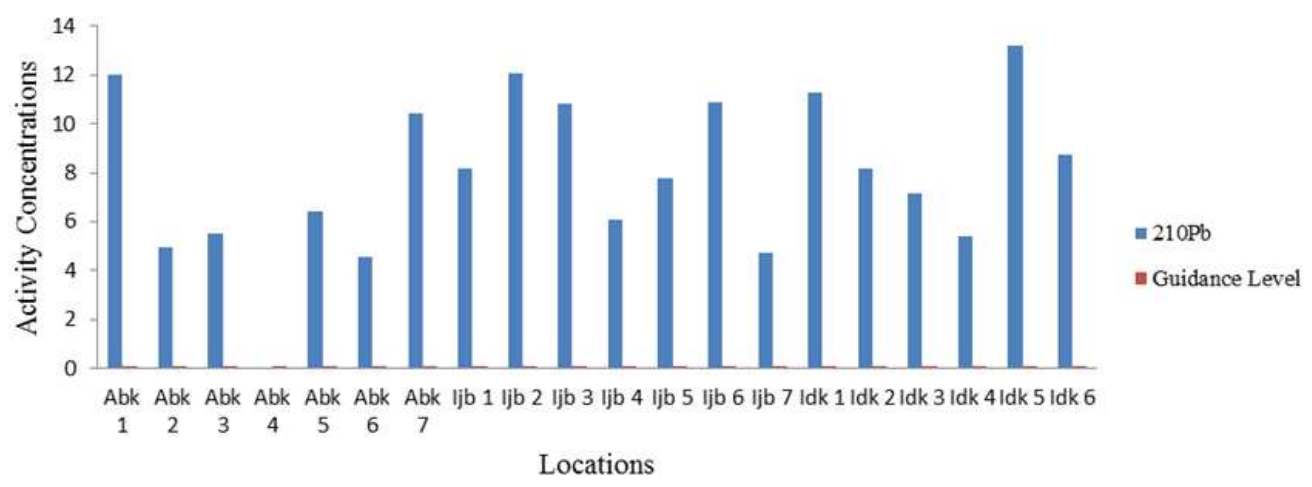

(a)

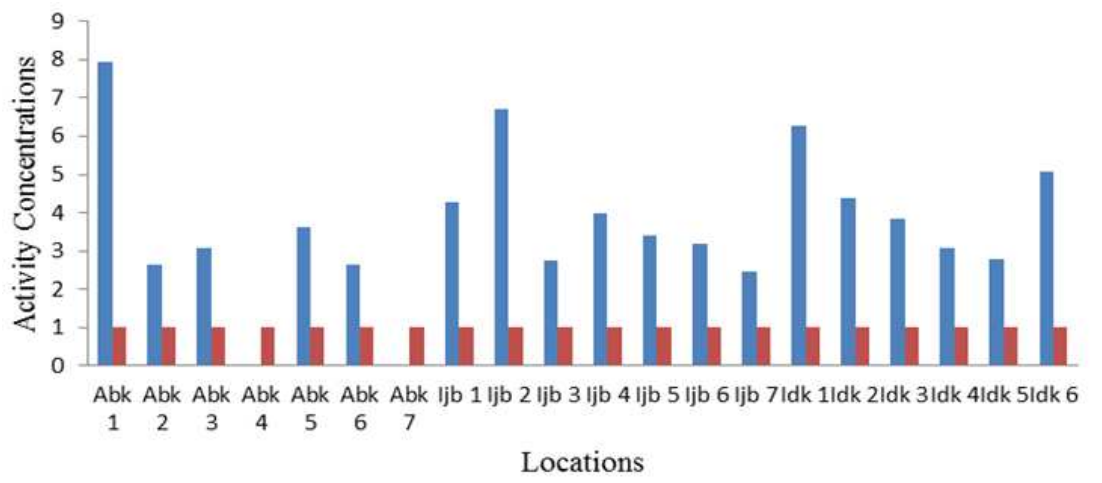

$=224 \mathrm{Ra}$

E Guidance Level

(b)

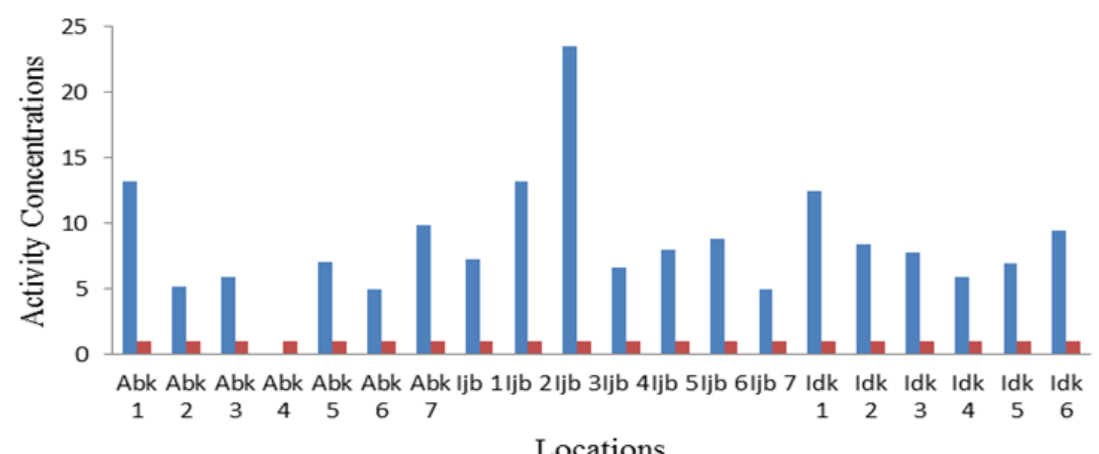

= 232Th

Guidance Level

(c) 


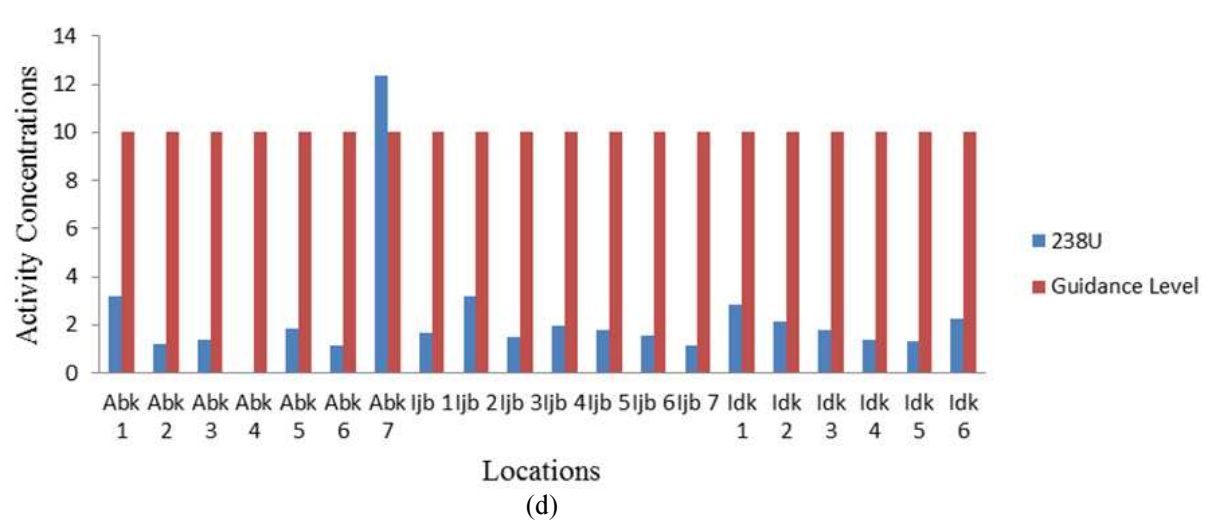

Fig. 3. a; b; c; d Comparison of activity concentrations of ${ }^{210} \mathrm{~Pb},{ }^{224} \mathrm{Ra},{ }^{232} \mathrm{Th}$ and ${ }^{238} \mathrm{U}$ with the WHO guidance level

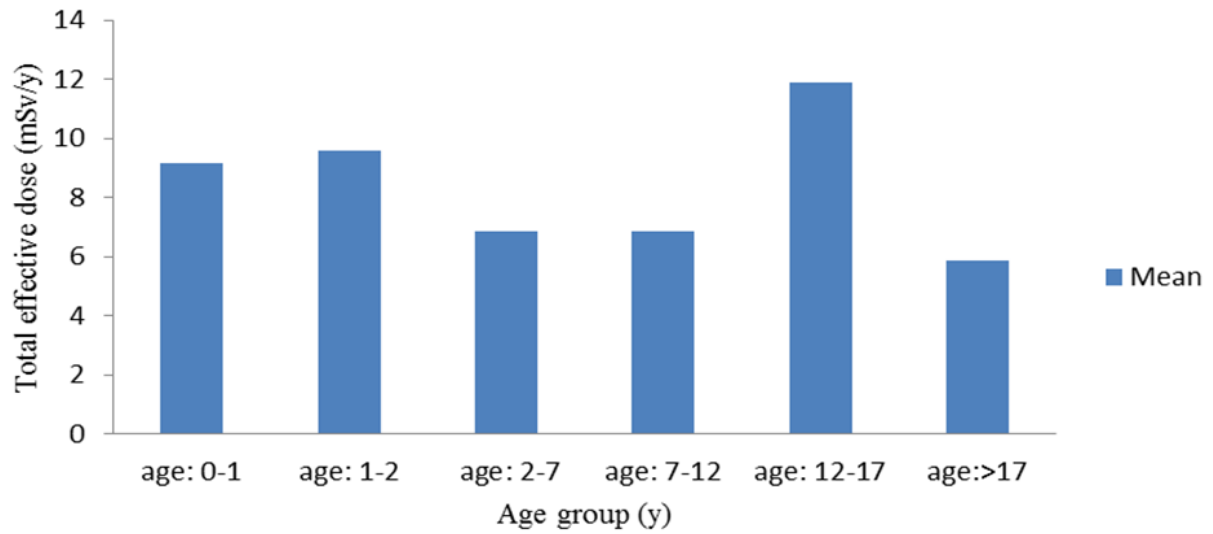

Fig. 4. Mean total annual effective dose

Table 1. Activity concentration of radionuclides in the water samples $\left(\mathrm{Bq}^{-1}\right)$

\begin{tabular}{|c|c|c|c|c|c|}
\hline Locations & ${ }^{40} \mathrm{~K}$ & ${ }^{210} \mathrm{~Pb}$ & ${ }^{224} \mathrm{Ra}$ & ${ }^{232} \mathrm{Th}$ & ${ }^{238} \mathrm{U}$ \\
\hline$\overline{\text { Abk } 1}$ & $0.17 \pm 1.27$ & $12.02 \pm 2.86$ & $7.94 \pm 6.43$ & $13.17 \pm 0.22$ & $3.22 \pm 1.06$ \\
\hline Abk 2 & $1.76 \pm 1.25$ & $4.98 \pm 2.18$ & $2.63 \pm 0.64$ & $5.17 \pm 1.51$ & $1.22 \pm 0.61$ \\
\hline Abk 3 & $2.05 \pm 1.07$ & $5.52 \pm 1.08$ & $3.09 \pm 0.52$ & $5.87 \pm 2.58$ & $1.37 \pm 0.12$ \\
\hline Abk 4 & $3.89 \pm 5.29$ & BDL & BDL & BDL & BDL \\
\hline Abk 5 & $0.63 \pm 0.83$ & $6.44 \pm 1.34$ & $3.62 \pm 1.04$ & $7.03 \pm 1.11$ & $1.83 \pm 0.23$ \\
\hline Abk 6 & $1.97 \pm 2.75$ & $4.58 \pm 1.27$ & $2.65 \pm 0.35$ & $4.97 \pm 1.47$ & $1.14 \pm 0.44$ \\
\hline Abk 7 & $3.71 \pm 0.05$ & $10.42 \pm 1.74$ & BDL & $9.87 \pm 1.40$ & $12.37 \pm 2.50$ \\
\hline Ijb 1 & $0.10 \pm 1.08$ & $8.17 \pm 0.52$ & $4.28 \pm 1.34$ & $7.23 \pm 1.06$ & $1.66 \pm 0.53$ \\
\hline Ijb 2 & $0.94 \pm 0.91$ & $12.08 \pm 1.29$ & $6.72 \pm 3.44$ & $13.26 \pm 11.67$ & $3.19 \pm 2.70$ \\
\hline Ijb 3 & $1.93 \pm 0.98$ & $10.85 \pm 7.28$ & $2.75 \pm 1.00$ & $23.52 \pm 8.67$ & $1.52 \pm 0.17$ \\
\hline Ijb 4 & $0.48 \pm 0.87$ & $6.10 \pm 4.49$ & $3.99 \pm 0.23$ & $6.67 \pm 1.98$ & $1.95 \pm 0.10$ \\
\hline Ijb 5 & $3.00 \pm 3.32$ & $7.78 \pm 3.73$ & $3.39 \pm 0.68$ & $7.99 \pm 0.39$ & $1.77 \pm 0.42$ \\
\hline Ijb 6 & $2.48 \pm 3.15$ & $10.91 \pm 0.85$ & $3.18 \pm 0.17$ & $8.82 \pm 0.62$ & $1.57 \pm 0.19$ \\
\hline Ijb 7 & $1.74 \pm 1.82$ & $4.73 \pm 2.74$ & $2.46 \pm 0.18$ & $4.95 \pm 0.33$ & $1.13 \pm 0.25$ \\
\hline Idk 1 & $0.81 \pm 0.90$ & $11.26 \pm 4.09$ & $6.26 \pm 3.11$ & $12.52 \pm 1.49$ & $2.83 \pm 0.76$ \\
\hline Idk 2 & $0.60 \pm 0.79$ & $8.15 \pm 6.48$ & $4.37 \pm 1.09$ & $8.44 \pm 2.37$ & $2.13 \pm 0.76$ \\
\hline Idk 3 & $3.31 \pm 4.00$ & $7.16 \pm 1.44$ & $3.85 \pm 0.31$ & $7.76 \pm 1.72$ & $1.79 \pm 0.28$ \\
\hline Idk 4 & $2.00 \pm 1.76$ & $5.43 \pm 0.40$ & $3.06 \pm 0.14$ & $5.90 \pm 0.70$ & $1.38 \pm 0.13$ \\
\hline Idk 5 & $2.18 \pm 0.66$ & $13.23 \pm 2.84$ & $2.77 \pm 2.83$ & $6.96 \pm 1.96$ & $1.35 \pm 0.03$ \\
\hline Idk 6 & $3.45 \pm 1.15$ & $8.75 \pm 1.43$ & $5.08 \pm 1.48$ & $9.47 \pm 0.70$ & $2.26 \pm 0.12$ \\
\hline Minimum & $0.10 \pm 1.08$ & BDL & BDL & BDL & BDL \\
\hline Maximum & $4.69 \pm 0.17$ & $13.23 \pm 2.84$ & $7.94 \pm 6.43$ & $23.52 \pm 8.67$ & $12.37 \pm 2.50$ \\
\hline Mean & $1.86 \pm 1.70$ & $7.93 \pm 2.40$ & $3.60 \pm 1.25$ & $8.48 \pm 2.10$ & $2.28 \pm 0.57$ \\
\hline GL & NE & 0.10 & 1.00 & 1.00 & 10.00 \\
\hline
\end{tabular}

Caption: Abk means Abeokuta; Ijb means Ijebu Ode; Idk means Idiroko; BDL means below detection limit; GL means guidance level and NE means not established 


\begin{tabular}{|c|c|c|c|c|c|c|}
\hline Locations & $0-1$ & $1-2$ & $2-7$ & $7-12$ & $12-17$ & $>17$ \\
\hline Abk 1 & $14.36 \pm 4.94$ & $14.25 \pm 3.84$ & $10.22 \pm 2.62$ & $10.13 \pm 2.54$ & $16.77 \pm 4.10$ & $8.75 \pm 1.82$ \\
\hline Abk 2 & $5.49 \pm 1.90$ & $5.75 \pm 2.35$ & $4.14 \pm 1.68$ & $4.10 \pm 1.67$ & $9.51 \pm 3.47$ & $3.54 \pm 1.40$ \\
\hline Abk 3 & $6.24 \pm 1.63$ & $6.43 \pm 1.40$ & $4.61 \pm 1.03$ & $4.58 \pm 1.03$ & $10.75 \pm 2.21$ & $3.97 \pm 0.99$ \\
\hline Abk 4 & - & - & - & - & & - \\
\hline Abk 5 & $7.34 \pm 1.57$ & $7.53 \pm 1.56$ & $5.41 \pm 1.11$ & $5.36 \pm 1.09$ & $12.59 \pm 2.89$ & $4.65 \pm 0.91$ \\
\hline Abk 6 & $5.25 \pm 1.28$ & $5.36 \pm 1.43$ & $3.85 \pm 1.04$ & $3.82 \pm 1.03$ & $6.34 \pm 1.73$ & $3.31 \pm 0.92$ \\
\hline Abk 7 & $11.62 \pm 1.36$ & $11.29 \pm 1.87$ & $7.95 \pm 1.36$ & $8.22 \pm 1.36$ & $13.86 \pm 2.30$ & $7.32 \pm 1.20$ \\
\hline Ijb 1 & $8.59 \pm 1.32$ & $9.28 \pm 0.85$ & $6.64 \pm 0.60$ & $6.59 \pm 0.59$ & $10.97 \pm 0.98$ & $5.57 \pm 0.52$ \\
\hline $\mathrm{Ijb} 2$ & $13.76 \pm 6.29$ & $14.11 \pm 3.25$ & $10.15 \pm 2.50$ & $10.07 \pm 2.41$ & $16.70 \pm 3.74$ & $8.73 \pm 2.86$ \\
\hline Ijb 3 & $14.27 \pm 6.80$ & $13.43 \pm 7.99$ & $9.96 \pm 5.82$ & $9.90 \pm 5.81$ & $16.29 \pm 9.72$ & $9.60 \pm 5.18$ \\
\hline $\mathrm{Ijb} 4$ & $7.26 \pm 2.91$ & $7.23 \pm 4.47$ & $5.20 \pm 3.19$ & $5.15 \pm 3.21$ & $8.51 \pm 5.45$ & $4.44 \pm 2.60$ \\
\hline Ijb 5 & $8.17 \pm 2.18$ & $8.85 \pm 3.67$ & $6.37 \pm 2.58$ & $6.33 \pm 2.58$ & $10.55 \pm 4.40$ & $5.48 \pm 1.99$ \\
\hline Ijb 6 & $9.82 \pm 0.71$ & $11.84 \pm 0.90$ & $8.50 \pm 0.65$ & $8.49 \pm 0.65$ & $14.20 \pm 1.08$ & $7.18 \pm 0.53$ \\
\hline Ijb 7 & $5.21 \pm 1.53$ & $5.47 \pm 2.63$ & $3.93 \pm 1.86$ & $3.90 \pm 1.87$ & $6.48 \pm 5.48$ & $3.37 \pm 1.44$ \\
\hline Idk 1 & $12.87 \pm 4.14$ & $13.16 \pm 4.55$ & $9.47 \pm 3.20$ & $9.40 \pm 3.17$ & $15.58 \pm 5.28$ & $6.27 \pm 2.48$ \\
\hline Idk 2 & $9.03 \pm 4.48$ & $9.44 \pm 6.56$ & $6.78 \pm 4.66$ & $6.73 \pm 4.67$ & $11.17 \pm 7.91$ & $5.81 \pm 3.73$ \\
\hline Idk 3 & $8.05 \pm 1.42$ & $8.33 \pm 1.60$ & $5.98 \pm 1.16$ & $5.94 \pm 1.17$ & $9.85 \pm 1.95$ & $5.15 \pm 1.05$ \\
\hline Idk 4 & $6.19 \pm 0.49$ & $6.34 \pm 0.47$ & $4.26 \pm 0.34$ & $4.52 \pm 0.35$ & $7.51 \pm 0.59$ & $3.93 \pm 0.32$ \\
\hline Idk 5 & $10.12 \pm 3.52$ & $13.71 \pm 3.38$ & $9.78 \pm 2.38$ & $9.79 \pm 2.35$ & $16.50 \pm 1.92$ & $8.00 \pm 1.89$ \\
\hline Idk 6 & $10.03 \pm 1.71$ & $10.24 \pm 1.67$ & $7.35 \pm 1.17$ & $7.29 \pm 1.15$ & $12.10 \pm 1.09$ & $6.31 \pm 0.91$ \\
\hline Mean & $9.14 \pm 2.64$ & $9.58 \pm 2.87$ & $6.87 \pm 2.05$ & $6.86 \pm 2.04$ & $11.91 \pm 3.49$ & $5.86 \pm 1.72$ \\
\hline
\end{tabular}

The total annual effective dose $\mathrm{E}_{\mathrm{T}}\left(\mathrm{Svy}^{-1}\right)$ to an individual is estimated by summing contributions from ${ }^{210} \mathrm{~Pb},{ }^{224} \mathrm{Ra},{ }^{232} \mathrm{Th}$ and ${ }^{238} \mathrm{U}$ present in the well water samples using Equation 2:

$E_{T}=\sum A_{C} I_{A} C_{F}$

The total annual effective dose $E_{T}\left(\mathrm{Svy}^{-1}\right)$ for six age groups from the ingestion of ${ }^{210} \mathrm{~Pb},{ }^{224} \mathrm{Ra},{ }^{232} \mathrm{Th}$ and ${ }^{238} \mathrm{U}$ using Equation 2 is presented in Table 2. Contribution from ${ }^{40} \mathrm{~K}$ was deliberately not included since it is homeostically controlled in the body (UNSCEAR, 2000). The absence of ${ }^{210} \mathrm{~Pb},{ }^{224} \mathrm{Ra},{ }^{232} \mathrm{Th}$ and ${ }^{238} \mathrm{U}$ in Abk 4 warranted the blank total effective dose. The total annual effective dose for the six age groups range from $5.21 \pm 1.53$ to $14.36 \pm 4.94 \mathrm{mSvy}^{-1} ; 5.36 \pm 1.43$ to $14.25 \pm 3.84 \mathrm{mSvy}^{-1}$; $3.85 \pm 1.04$ to $10.22 \pm 2.62 \mathrm{mSvy}^{-1} ; 3.82 \pm 1.03$ to $10.13 \pm 2.54$ $\mathrm{mSvy}^{-1} ; 6.34 \pm 1.73$ to $16.77 \pm 4.10 \mathrm{mSvy}^{-1}$; and $3.31 \pm 0.92$ to $8.75 \pm 1.82 \mathrm{mSvy}^{-1}$ for ages $0-1 \mathrm{y} ; 1-2 \mathrm{y} ; 2-7 \mathrm{y} ; 7-12 \mathrm{y} ; 12-$ $17 \mathrm{y}$; and $>17 \mathrm{y}$ respectively. All the values for the six age groups exceeded the World Health Organization (WHO) recommended standard of $0.1 \mathrm{mSvy}^{-1}$.

\section{Evaluation of Lifetime Cancer Risks}

The lifetime cancer Risks ( $R$ ) associated with intake of a given radionuclide was evaluated using Equation 3 according to Amakom and Jibiri (2010):

$$
R=r A_{C} I_{A} L_{E}
$$

where, $R$ means lifetime cancer risks; $r$ is cancer risk coefficient; $A_{C}$ is activity concentration; $I_{A}$ is the annual water consumption; and $L_{E}$ is life expectancy at birth. The cancer risk coefficients of ${ }^{40} \mathrm{~K},{ }^{210} \mathrm{~Pb},{ }^{224} \mathrm{Ra},{ }^{232} \mathrm{Th}$ and ${ }^{238} \mathrm{U}$ for mortality and morbidity were obtained from USEPA (2000). Annual water intake for adult was 7301 and life expectancy at birth in Nigeria was 54.5 according to the World Health Organization (WHO, 2015) report.

Lifetime cancer risks estimate is tabulated for mortality risks and morbidity risks as shown in Table 3. Mean cancer mortality risks for ${ }^{40} \mathrm{~K},{ }^{210} \mathrm{~Pb},{ }^{224} \mathrm{Ra},{ }^{232} \mathrm{Th}$ and ${ }^{238} \mathrm{U}$ is $3.16 ; 575.74 ; 43.25 ; 63.37$; and $10.70\left(\times 10^{-5}\right)$ respectively. The mean cancer morbidity risks is 5.00; 759.67; 71.05; 96.03 ; and $16.40\left(\times 10^{-5}\right)$ for ${ }^{40} \mathrm{~K}, \quad{ }^{210} \mathrm{~Pb}$, ${ }^{224} \mathrm{Ra},{ }^{232} \mathrm{Th}$ and ${ }^{238} \mathrm{U}$ respectively. ${ }^{40} \mathrm{~K}$ has the least value for both mortality and morbidity cancer risks estimate while ${ }^{210} \mathrm{~Pb}$ has the highest value for both mortality and morbidity cancer risks estimate in all water samples of the study area.

\section{Discussion}

\section{Discussion on Activity Concentrations of the Water Samples}

The presence of ${ }^{40} \mathrm{~K}$ in all the water samples is indicative of its wide distribution and abundance in nature. Research has shown that ${ }^{40} \mathrm{~K}$ represents $0.012 \%$ of naturally occurring potassium that is found in large amounts throughout nature. Though homeostatically controlled in the body, its decay mechanism is associated with cell damage and renders it potent for cancer induction. Lifetime cancer mortality risk due to its ingestion is estimated as $2.2 \times 10^{-11} \mathrm{pCu}^{-1}$ (Peterson et al., 2007). Absence of ${ }^{210} \mathrm{~Pb},{ }^{224} \mathrm{Ra},{ }^{232} \mathrm{Th}$ and ${ }^{238} \mathrm{U}$ in Abk 4 could be attributed to the depth of the well. It was the only well where the presence of ${ }^{88} \mathrm{Y},{ }^{103} \mathrm{Ru},{ }^{131} \mathrm{I},{ }^{144} \mathrm{Ce}$ and ${ }^{192} \mathrm{Ir}$ was detected. Other factors may be due to the wide variations in the concentrations of natural radionuclides even within very small confine (UNSCEAR, 2000). Also, slow movement of groundwater through aquifer resulting in groundwater contamination not been discovered long after it has occurred (USEPA, 2000). 
Increased activity concentration in this study is expected. High radionuclides concentrations have been envisaged in water resources of the study area (Jibiri et al., 2010). Also, the geological formation of the area is known to be associated with elevated concentrations of radionuclides (Olurin et al., 2012; Farai and Vincent 2006). Similar studies have confirmed same in other part of the world (Bajwa et al., 2015; Jurgens et al., 2010; Believermis et al., 2009; UNSCEAR, 2000). The type and values of radionuclides recorded in Table 1 conform well to literature. Groundwater exhibits various forms of radionuclides that vary extensively in concentrations due to varying geology and disjointed aquifers. The chemical nature of radionuclide is another factor that influences the disparity in the concentration of radionuclides in ground water. (Kleinschmidt and Akber, 2008; IAEA, 1990). Anthropogenic impacts on the study environment are other factor traceable to the elevated level of their radionuclides. Groundwater pollution of the study area arising from point and non-point sources has been reported in literature (Ojekunle et al., 2016; Adekunle et al., 2013; Olurin et al., 2012).

The presence of ${ }^{210} \mathrm{~Pb}$ and ${ }^{224} \mathrm{Ra}$ in this study is significant. As far as we know, their concentrations have not been determined or reported in literature in any water resources of the study area. Hence, the value reported in this study will serve as a base line data for future studies. However, several Researchers have investigated these radionuclides in different part of the world (Persson 2014; Jia et al., 2009; Kleinschmidt and Akber 2008; Szabo et al., 2005). Varying concentrations from low to very high levels were reported. High concentration of ${ }^{210} \mathrm{~Pb}$ in well water was considered to be an ingrowth from dissolved ${ }^{222} \mathrm{Rn}$ (Manu et al., 2014; Kleinschmidt and Akber 2008). Contrarily, the distribution of ${ }^{224} \mathrm{Ra}$ was related to the presence of other constituents and to the physical characteristics of the aquifer system (Szabo et al., 2005).

Ogun State play host to the highest number of University campuses in Nigeria, it borders with several States and the Republic of Benin. Its proximity to Lagos metropolis subjects it to massive population explosion. The aftermath is rapid urbanization, industrialization and increased waste generation. Invariably, waste management is a major challenge. Therefore, high concentrations of radionuclides are inevitable in the study area because most well in this vicinity are of shallow origin and are liable to surface contamination (Orebiyi et al., 2010; Olurin et al., 2012).

\section{Discussion on Radiological Risks}

The result of total annual effective dose $\left(E_{T}\right)$ for this study compared well with literature according to UNSCEAR (2013). Their report revealed that infants and children are more sensitive to radiation than adults and oftentimes are prone to higher radiation risks. They also affirmed radiation risks variability in children at different age groups especially in cancer induction. The age dependent factors that contribute to variation in radiation effects and risks includes: Size of individual and organs; growth patterns of the individual and tissues; intake and absorption of radiation; metabolic rates; and physical activities among others (UNSCEAR, 2013).

The high total annual effective dose is due to the high activity concentrations of ${ }^{210} \mathrm{~Pb},{ }^{224} \mathrm{Ra}$ and ${ }^{232} \mathrm{Th}$, with major contribution from ${ }^{210} \mathrm{~Pb}$. These finding compared well with literature as the concentration of ${ }^{210} \mathrm{~Pb}$ does not depend on the concentration of its parent isotopes in a medium (Bonczyk, 2013; Health Canada, 2009). Rather, its contribution to dose by ingestion is known to be potentially large (Casacuberta et al., 2010).

The contribution of ${ }^{210} \mathrm{~Pb},{ }^{224} \mathrm{Ra},{ }^{232} \mathrm{Th}$ and ${ }^{238} \mathrm{U}$ to the total annual effective dose as presented in Table 4 showed that ${ }^{210} \mathrm{~Pb}$ was the highest contributor. It contributed $43.8 \%$ of the mean total annual effective dose for age $0-1 \mathrm{y} ; 81.5$ for $1-2 \mathrm{y} ; 80.2 \%$ for $2-7 ; 80.9 \%$ for $7-12 ; 79.9 \%$ for $12-17 \mathrm{y}$ and $71.7 \%$ for $>17 \mathrm{y}$. Percent contribution of ${ }^{232} \mathrm{Th}$ to the mean total annual effective dose was $31.26 \% ; 10.86 \%$; $13.68 \% ; 13.21 \% ; 11.25 \%$ and $23.17 \%$ for ages $0-1 \mathrm{y} ; 1-2 \mathrm{y}$; $2-7$ y; 7-12 y; 12-17 y and $>17$ y respectively. Next was ${ }^{224} \mathrm{Ra}$ with percent contribution of $22.40 \% ; 6.78 \% ; 5.82 \%$; $5.03 \% ; 8.04 \%$; and $3.24 \%$ for ages $0-1 \mathrm{y} ; 1-2 \mathrm{y} ; 2-7 \mathrm{y} ; 7-12$ $\mathrm{y} ; 12-17 \mathrm{y}$ and $>17 \mathrm{y}$ respectively. The least contributor was ${ }^{238} \mathrm{U}$ with an estimate of $2.51 \% ; 0.83 \% ; 0.87 \% ; 0.84 \%$; $0.82 \%$; and $1.37 \%$ for ages $0-1 \mathrm{y} ; 1-2 \mathrm{y} ; 2-7 \mathrm{y} ; 7-12 \mathrm{y} ; 12-$ $17 \mathrm{y}$ and $>17 \mathrm{y}$ respectively.

The mortality and morbidity cancer risks estimate for ${ }^{210} \mathrm{~Pb}$ was the highest. This is attributable to its high activity concentration in the water samples. Study has shown that ${ }^{210} \mathrm{~Pb}$ concentrate in bones (Health Canada, 2009). Also, being a by-product of ${ }^{222} \mathrm{Rn}$, its presence in any tissue where its parent isotope is found cannot be overruled. This calls for proper evaluation of ${ }^{210} \mathrm{~Pb}$. The mortality and morbidity cancer risks estimate for ${ }^{238} \mathrm{U}$ in this study compared well with that obtained by Amakom and Jibiri (2010). This is likely due to the close proximity of the two study areas as both areas have similar geological formation. However, the mortality and morbidity cancer risks estimate for ${ }^{238} \mathrm{U}$ in this study was higher than that obtained by Maxwell et al. (2015). This disparity can linked to the high radionuclides contents in this present study environment. Different geological formation of the two study areas can also be a contributing factor. High levels of ${ }^{238} \mathrm{U}$ and ${ }^{232} \mathrm{Th}$ series in drinking water increase the risk of certain cancers in the body (Colorado Health and Environmental Assessment, 2013; Wagner et al., 2011; Kurttio et al. 2006). ICRP (2007) noted that ingested radionuclides are absorbed in the blood stream and accumulate in specific tissues causing damage. Cells in kidney and bladder are irradiated when radionuclides are excreted in urine (Kurttio et al., 2006). Hence, the result of this study should be addressed by the appropriate authorities in the respective level of governance. Adequate measures that will alleviate the high radiation risk associated with drinking water from these wells should be adopted. 
Table 3. Lifetime cancer risks

\begin{tabular}{|c|c|c|c|c|c|c|c|c|c|c|}
\hline \multirow[b]{2}{*}{ Locations } & \multicolumn{5}{|c|}{ Locations cancer mortality risks $(10-5)$} & \multicolumn{5}{|c|}{ Cancer morbidity risks (10-5) } \\
\hline & ${ }^{40} \mathrm{~K}$ & ${ }^{210} \mathrm{~Pb}$ & ${ }^{224} \mathrm{Ra}$ & ${ }^{232} \mathrm{Th}$ & ${ }^{238} \mathrm{U}$ & ${ }^{40} \mathrm{~K}$ & ${ }^{210} \mathrm{~Pb}$ & ${ }^{224} \mathrm{Ra}$ & ${ }^{232} \mathrm{Th}$ & ${ }^{238} \mathrm{U}$ \\
\hline Abk 1 & 0.29 & 836.83 & 86.55 & 97.98 & 14.49 & 0.45 & 1138.17 & 142.13 & 143.03 & 22.15 \\
\hline Abk 2 & 3.01 & 346.71 & 28.67 & 38.46 & 5.49 & 4.68 & 471.56 & 47.08 & 56.15 & 8.39 \\
\hline Abk 3 & 3.51 & 384.30 & 33.68 & 43.67 & 6.17 & 5.45 & 522.69 & 55.31 & 63.75 & 9.43 \\
\hline Abk 4 & 6.65 & 0.00 & 0.00 & 0.00 & 0.00 & 10.35 & 0.00 & 0.00 & 0.00 & 0.00 \\
\hline Abk 5 & 0.74 & 448.35 & 39.46 & 50.30 & 8.24 & 1.68 & 609.80 & 64.80 & 76.35 & 12.59 \\
\hline Abk 6 & 3.37 & 318.86 & 28.89 & 36.97 & 5.13 & 5.24 & 433.68 & 47.44 & 53.97 & 7.84 \\
\hline Abk 7 & 6.34 & 725.38 & 0.00 & 73.43 & 55.67 & 9.87 & 986.67 & 0.00 & 107.19 & 85.11 \\
\hline Ijb 1 & 0.17 & 568.80 & 46.65 & 53.79 & 7.47 & 0.27 & 773.62 & 76.61 & 78.52 & 11.42 \\
\hline $\mathrm{Ijb} 2$ & 1.61 & 841.01 & 73.25 & 98.65 & 14.36 & 2.50 & 1143.85 & 120.29 & 144.00 & 21.95 \\
\hline Ijb 3 & 3.30 & 755.38 & 29.98 & 174.98 & 6.84 & 5.13 & 1027.38 & 49.23 & 255.43 & 10.46 \\
\hline $\mathrm{Ijb} 4$ & 0.82 & 424.68 & 43.49 & 49.62 & 8.78 & 1.28 & 577.61 & 71.42 & 72.44 & 13.42 \\
\hline $\mathrm{Ijb} 5$ & 5.13 & 541.64 & 36.95 & 59.45 & 7.97 & 7.98 & 736.69 & 60.68 & 86.77 & 12.18 \\
\hline $\mathrm{Ijb} 6$ & 4.24 & 759.55 & 34.66 & 65.62 & 7.07 & 6.60 & 1033.07 & 56.92 & 95.79 & 10.80 \\
\hline $\mathrm{Ijb} 7$ & 2.97 & 329.30 & 26.81 & 36.83 & 5.09 & 5.63 & 447.88 & 44.03 & 53.76 & 7.77 \\
\hline Idk 1 & 1.39 & 783.92 & 68.23 & 93.15 & 12.74 & 2.15 & 1066.21 & 112.05 & 135.97 & 19.47 \\
\hline Idk 2 & 1.03 & 567.40 & 47.63 & 62.79 & 9.59 & 1.60 & 771.72 & 78.22 & 91.66 & 14.65 \\
\hline Idk 3 & 5.66 & 498.48 & 41.97 & 57.73 & 8.06 & 8.80 & 677.98 & 68.92 & 84.27 & 12.32 \\
\hline Idk 4 & 3.42 & 378.04 & 33.35 & 43.90 & 6.21 & 5.32 & 514.17 & 54.77 & 64.07 & 9.49 \\
\hline Idk 5 & 3.73 & 921.07 & 30.19 & 51.78 & 6.08 & 5.80 & 1252.74 & 49.58 & 75.59 & 9.29 \\
\hline Idk 6 & 5.90 & 609.18 & 55.37 & 70.45 & 10.17 & 9.18 & 828.53 & 90.93 & 102.84 & 15.55 \\
\hline Mean & 3.16 & 580.95 & 43.61 & 66.29 & 10.82 & 5.00 & 790.21 & 71.69 & 96.92 & 16.54 \\
\hline
\end{tabular}

Table 4. Contribution of ${ }^{210 \mathrm{P}} \mathrm{b},{ }^{224} \mathrm{Ra},{ }^{232} \mathrm{Th}$ and ${ }^{238} \mathrm{U}$ to the mean total annual effective dose $\left(\mathrm{mSvy}^{-1}\right)$

\begin{tabular}{|c|c|c|c|c|c|}
\hline Age groups & ${ }^{210} \mathrm{~Pb}$ & ${ }^{224} \mathrm{Ra}$ & ${ }^{232} \mathrm{Th}$ & ${ }^{238} \mathrm{U}$ & Total dose \\
\hline \multicolumn{6}{|c|}{ Mean total annual effective dose $\left(\mathrm{mSvy}^{-1}\right)$} \\
\hline $0-1$ & 4.01 & 2.05 & 2.86 & 0.23 & 9.15 \\
\hline $1-2$ & 7.81 & 0.65 & 1.04 & 0.08 & 9.58 \\
\hline $2-7$ & 5.51 & 0.40 & 0.94 & 0.06 & 6.87 \\
\hline $7-12$ & 5.55 & 0.34 & 0.91 & 0.06 & 6.86 \\
\hline $12-17$ & 9.51 & 0.96 & 1.34 & 0.10 & 11.91 \\
\hline$>17$ & 4.20 & 0.19 & 1.40 & 0.08 & 5.86 \\
\hline \multicolumn{6}{|c|}{ Contribution (\%) } \\
\hline $0-1$ & 43.82 & 22.40 & 31.26 & 2.51 & 100.00 \\
\hline $1-2$ & 81.52 & 6.78 & 10.86 & 0.83 & 100.00 \\
\hline $2-7$ & 80.20 & 5.82 & 13.68 & 0.87 & 100.00 \\
\hline $7-12$ & 80.92 & 5.03 & 13.21 & 0.84 & 100.00 \\
\hline $12-17$ & 79.90 & 8.04 & 11.25 & 0.82 & 100.00 \\
\hline$>17$ & 71.67 & 3.24 & 23.89 & 1.37 & 100.00 \\
\hline
\end{tabular}

\section{Conclusion}

The activity concentrations of ${ }^{40} \mathrm{~K},{ }^{210} \mathrm{~Pb},{ }^{224} \mathrm{Ra}$, ${ }^{232} \mathrm{Th}$ and ${ }^{238} \mathrm{U}$ were measured in drinking waters of Ogun State using gamma spectrometry. Their mean activity concentrations were found to be $1.86 \pm 1.70$ $\mathrm{Bql}^{-1} ; 7.93 \pm 2.40 \mathrm{Bql}^{-1} ; 3.60 \pm 1.25 \mathrm{Bql}^{-1} ; 8.48 \pm 2.10$ $\mathrm{Bql}^{-1}$; and 2.28 $\pm 0.57 \mathrm{Bql}^{-1}$ respectively. These mean activities exceeded the World Health Organization recommended guidance level in all the water samples of this study for ${ }^{210} \mathrm{~Pb},{ }^{224} \mathrm{Ra}$ and ${ }^{232} \mathrm{Th}$.

Consequently, the cumulative annual effective dose resulting from the ingestion of these radionuclides for six different age groups are: 9.14 $\mathrm{mSv} \mathrm{y}^{-1} ; 9.58 \mathrm{mSv} \mathrm{y}^{-1} ; 6.87 \mathrm{mSv} \mathrm{y}^{-1} ; 6.86 \mathrm{mSv} \mathrm{y}^{-1}$; $11.91 \mathrm{mSv} \mathrm{y}^{-1}$; and $5.68 \mathrm{mSv} \mathrm{y}^{-1}$ for ages $0-1 \mathrm{y} ; 1-2$ y; 2-7 y; 7-12 y; 12-17 y and $>17$ y respectively. These derived values also exceeded $0.1 \mathrm{~m} \mathrm{~Sv} \mathrm{y}^{-1}$ recommended by the World Health Organization in all the water samples. The mean cancer mortality and morbidity risks respectively were found to have least value for ${ }^{40} \mathrm{~K}\left\{(3.16\right.$ and 5.00$\left.) 10^{-5}\right\}$ and highest value for ${ }^{210} \mathrm{~Pb}\left\{(575.74\right.$ and 759.67$\left.) 10^{-5}\right\}$. This is indicative that there is high radiation risk in drinking the water from these wells. Therefore, it is strongly recommended that these wells should be treated especially for ${ }^{210} \mathrm{~Pb}$ whose contribution resulted in the increased risks. Also, further research on the trends of radionuclides in the study area should be investigated.

\section{Acknowledgement}

The authors are grateful to Covenant University Ota, Ogun State, Nigeria for funding the publication of this article. 


\section{Funding Information}

The processing cost of this manuscript was funded by Covenant University Ota, Ogun State, Nigeria.

\section{Author's Contributions}

Justina Ada Achuka: Initiated the idea, collected the data and contributed to the preparation of the manuscript.

Usikalu Mojisola Rachael: Developed the plan and contributed to the preparation of the manuscript.

Oyeyemi Kehinde David: Analyzed the data graphically and contributed to the preparation of the manuscript.

\section{Ethics}

There is no known ethical issue or conflict of interest that may arise after the publication of this manuscript.

\section{References}

Adedeji, O.H., H.O. Adebayo and E.I. Sotayo, 2014. Assessing environmental impacts of inland sand mining in parts of Ogun State, Nigeria. Ethiopian J. Environ. Stud. Management, 7: 478-487.

Adekunle, A.A., A.O. Badejo and A.O. Oyerinde, 2013. Pollution studies on groundwater contamination: Water quality of Abeokuta, Ogun State, South West Nigeria. J. Environ. Earth Sci., 3: 161-166.

AMCOW, 2012. A snapshot of drinking water and sanitation in Africa. Fourth African Water Week, Cairo Egypt, 1: 2-7.

Akujieze, C.N., S. Coker and G. Oteze, 2003. Groundwater in Nigeria-a millennium experiencedistribution, practice, problems and solutions. Hydrogeol. J., 11: 259-274. DOI: $10.1007 / \mathrm{s} 10040-002-0227-3$

Aladejana, J.A. and A.O. Talabi, 2013. Assessment of groundwater quality in Abeokuta Southwestern, Nigeria. Int. J. Eng. Sci., 2: 21-31.

Alausa, S.K., O.O. Fasunwon and K. Odunaike, 2014. Activity and corresponding mass concentrations of ${ }^{40} \mathrm{~K}$ and ${ }^{238}$ Uin well waters from ago-Iwoye, Ogun State, Nigeria. J. Natural Sci. Res., 4: 1-5.

Amakom, C.M. and N.N. Jibiri, 2010. Chemical and radiological risk assessment of uranium in borehole and well water waters in the Odeda Area, Ogun State, Nigeria. Int. J. Physical Sci., 5: 1009-1014.

APHA, 1999. Standard methods for the examination of water and wastewater. American Public Health Association, American Water Works Association, Water Environment Federation. APHA.

Auvinen, A., P. Kurttio, J. Pekkanen, E. Pukkala and T. Ilus et al., 2002. Uranium and other natural radionuclides in drinking water and risk of leukemia: A case-cohort study in Finland. Cancer Causes Control, 13: 825-829.

Auvinen, A., L. Salonen, J. Pekkanen, E. Pukkala and T. Ilus et al., 2005. Radon and other natural radionuclides in drinking water and risk of stomach cancer: A case-cohort study in Finland. Int. J. Cancer, 114: 109-113.

Bajwa, B.S., S. Kumar, S. Singh, S.K. Sahoo and R.M. Tripathi, 2015. Uranium and other heavy toxic elements distribution in the drinking water samples of SW-Punjab, India. J. Radiation Res. Applied Sci., 10: 1-9. DOI: 10.1016/j.jrras.2015.01.002

Believermis, M., O. Kilic, Y. Cotuk and S. Topcuoğlu, 2009. The effects of physicochemical properties on gamma emitting natural radionuclide levels in the soil profile of Istanbul. Environ. Monit. Assess., 163: 15-16. DOI: 10.1007/s10661-009-0812-1

Bonczyk, M., 2013. A determination of the concentration level of lead ${ }^{210} \mathrm{~Pb}$ isotope in solid samples for the assessment of radiation risk occuring in coal mines. J. Sustainable Mining, 12: 1-7. DOI: $10.7424 /$ jsm 130201

Canu, G., O. Laurent, N. Pires, D. Laurier and I. Dublineau, 2011. Health effects of naturally radioactive water ingestion: The need for enhanced studies. Environmental Health Perspectives, 119: 1676-1680.

Casacuberta, N., F.L. Traversa, P. Masque, J. GarciaOrellana and M. Anguita et al., 2010. $\mathrm{Po}^{210}$ in poultry due to ingestion of dicalcium phosphate. Sci. Environ., 408: 4695- 4701.

Cech, I., A. Patnaik, K.D. Burau and M.H. Smolensky, 2008. Spatial distribution of orofacial cleft defect births in Harris County, Texas and radium in the public water supplies: A persistent association? Texas Med., 104: 56-63.

Colorado Health and Environmental Assessment, 2013. Physical environment: Water. CHEA.

Farai, I.P. and U.E. Vincent, 2006. Out-door radiation level measurement in Abeokuta Nigeria by Thermoluminiscent Dosimetry. Nigerian J. Physics, 18: 121-126.

Health Canada, 2009. Guidelines for Canadian Drinking Water Quality: Guideline Technical Document. 1st Edn., Health Canada, Ottawa, ISBN-10: 1100105085 , pp: 82.

IAEA, 1989. Measurement of radiation in food and the environment. Technical Report series No. 295, Vienna.

IAEA, 1990. The Environmental Behaviour of Radium. 1st Edn., International Atomic Energy Agency, Vienna, pp: 446.

IAEA, 1996. Basic Safety Standards. Technical Report series No. 15, IAEA, Vienna.

ICRP, 2007. Recommendations of the international commission on radiological protection. ICRP Publication 103. J. Valentin. Annals, 37: 1-332. 
ICRP, 2012. Annals of the ICRP; ICRP Publication 119: Compendium of dose coefficient based on ICRP Publication. ICRP, 42: 71-86

Jacobsen, M., M. Webster and K. Vairavamoorthy, 2012. The Future of Water in African Cities: Why Waste Water? 1st Edn., World Bank Publications, Washington, ISBN-10: 0821397222, pp: 224.

Jia, G., G. Torri and L. Magro, 2009. Concentrations of ${ }^{238} \mathrm{U},{ }^{234} \mathrm{U},{ }^{235} \mathrm{U},{ }^{232} \mathrm{Th},{ }^{230} \mathrm{Th},{ }^{228} \mathrm{Th},{ }^{226} \mathrm{Ra},{ }^{228} \mathrm{Ra}$, ${ }^{224} \mathrm{Ra},{ }^{210} \mathrm{Po},{ }^{210} \mathrm{~Pb}$ and ${ }^{212} \mathrm{~Pb}$ in drinking water in Italy: Reconciling safety standards based on measurements of gross $\alpha$ and $\beta$. J. Environ. Radioactivity, 100: 941-949.

Jibiri, N.N., C.M. Amakom and G.O. Adewuyi, 2010. Radionuclide contents and physicochemical water quality indicators in stream, well and borehole water sources in high radiation area of Abeokuta, Southwestern Nigeria. J. Water Resource Protection, 2: 291-297.

Jurgens, B.C., M.S. Fram, K. Belitz, K.R. Burow and M.K. Landon, 2010. Effects of groundwater development on uranium: Central Valley, California, USA. Groundwater, 48: 913-928.

Kelleher, S., 2015. New study reveals how much groundwater remains. Earth Space Sci. News. DOI: $10.1029 / 2015 \mathrm{EO} 040089$

Kleinschmidt, R. and R. Akber, 2008. Naturally occurring radionuclides in materials derived from urban water treatment plants in Southeast Queensland, Australia. J. Environ. Radioactivity, 99: 607-620.

Kurttio, P., L. Salonen, T. Ilus, J. Pekkanen and E. Pukkala et al., 2006. Well water radioactivity and risk of cancers of the urinary organs. Environ. Res., 102: 333-338. DOI: 10.1016/j.envres.2005.12.010

Manu, A., V. Santhanakrishnan, S. Rajaram and P.M. Ravi, 2014. Concentration of natural radionuclides in raw water and packaged drinking water and the effect of water treatment. J. Environ. Radioactivity, 138: 456-459. DOI: 10.1016/j.jenvrad.2014.08.013

Maxwell, O., H. Wagiran, S.K. Lee, Z. Embong and P.E. Ugwuoke, 2015. Radioactivity level and toxic elemental concentration in ground water at dei-dei and Kubwa areas of Abuja, North Central Nigeria. Radiation Phys. Chem., 107: 23-30. DOI: 10.1016/j.radphyschem.2014.09.003

NBS, 2012. Annual abstracts of statistics. Federal Republic of Nigeria.

Ndontchueng, M.M., A. Simo, E.J.M. Nguelem, J.F. Beyala and D. Kryeziu, 2013. Preliminary study of natural radioactivity and radiological risk assessment in some mineral bottled water produced in Cameroon. Int. J. Sci. Technol., 3: 271-276.

Nwankwo, L.I. and A.A. Balogun, 2014. Assessment of natural radioactivity in sachet drinking-water samples in Nigeria, West Africa. Work. Living Environ. Protect., 11: 43-51.
Odukoya, O.O., P.C. Onianwa and O.I. Sanusi, 2010. Effect of highways and local activities on the quality of underground water in Ogun State, Nigeria. Environ. Monitor. Assess., 168: 1-10.

Ojekunle, O.Z., O.V. Ojekunle, A.A. Adeyemi, A.G. Taiwo and O.R. Sangowusi et al., 2016. Evaluation of surface water quality indices and ecological risk assessment for heavy metals in scrap yard neighbourhood. Springer Plus, 5: 1-16

Okeyode, I.C., 2012. Radiogenic heat production due to natural radionuclides in the sediments of Ogun River, Nigeria. J. Environ. Earth Sci., 2: 196-207.

Olurin, O.T., B.S. Badmus, O.D. Akinyemi, J.A. Olowofela and V.C. Ozebo, 2012. Analysis of physical parameters of limestone deposits in Ewekoro formation, Southwestern Nigeria. Earth Sci. Res., 1: 117-121.

Orebiyi, E.O., J.A. Awomeso and J.A. Oyedepo, 2008. Assessment of bacteria pollution of shallow well water in Abeokuta, Southwestern Nigeria. Life Sci. J., 5: 59-65.

Orebiyi, E.O., J.A. Awomeso, O.A. Idowu, O. Martins and O. Oguntoke et al., 2010. Assessment of pollution hazards of shallow well water in Abeokuta and environs, Southwest, Nigeria. Am. J. Environ. Sci., 6: 50-56

Persson, B.R.R., 2014. ${ }^{210} \mathrm{Po}$ and ${ }^{210} \mathrm{~Pb}$ in the terrestrial environment. Curr. Adv. Environ. Sci., 2: 22-37.

Peterson, J., M. MacDonell, L. Haroun and F. Monette, R.D. Hildebrand et al., 2007. Radiological and chemical fact sheets to support health risk analyses for contaminated areas. Environ. Sci. Division Argonne National Laboratory.

Phatcha, H., S. Hutcha and G. Alan, 2006. Radiumcontaminated water: A risk factor for cancer of the upper digestive tract. Asian Pac. J. Cancer Prev., 7: 295-298. PMID: 16839204

Rachkova, N.G. and I.I. Shuktomova, 2015. U and Th distribution in podzolic soil contaminated with soluble compounds of these elements. Goechem. Int., 53: 182-189. DOI: 10.1134/S0016702915020068

Szabo, Z., V.T. DePaul, T.F. Kraemer and B. Parsa, 2005. Occurrence of Radium-224, Radium-226 and Radium-228 in Water of the Unconfined KirkwoodCohansey Aquifer System, Southern, New Jersey. 1st Edn., U.S. Geological Survey. Reston, pp: 92.

UNEP, 2010. Africa Water Atlas. 1st Edn., UNEP/Earthprint, Nairobi, Kenya, ISBN-10: 9280731106, pp: 314.

UNSCEAR, 2000. Sources and Effects of Ionizing Radiation: Sources. 1st Edn., United Nations Publications, New York United Nations, ISBN-10: 9211422388 , pp: 654. 
UNSCEAR, 2013. Sources, effects and risks of ionizing radiation. UNSCEAR 2013 Report to the General Assembly with Scientific Annexes. UNSCEAR.

USEPA, 2000. National Water Quality Inventory: Report to Congress. 1st Edn., Office of Water Regulations and Standards, Washington, D.C.

Wagner, S.E., J.B. Burch, M. Bottai, R. Puett and D. Porter et al., 2011. Groundwater uranium and cancer incidence in South Carolina. Cancer Causes Control, 22: 41-50.
Winter, T.C., J.W. Harvey, O.L. Franke and W.M. Alley, 1998. Ground Water and Surface Water: A Single Resource. 1st Edn., U.S. Geological Survey, Denver, pp: 79.

WHO, 2015. WHO statistical profile. Country Statistics and Global Health Estimates by WHO and UN Partners. Global Health Observatory, World Health Organization.

WHO, 2011. Guidelines for Drinking Water Quality. 1st Edn., World Health Organization, Geneva, ISBN-10: 9241541687, pp: 465. 